\title{
TWO EARLY SITES OF EASTERN BERINGIA: CONTEXT AND CHRONOLOGY IN ALASKAN INTERIOR ARCHAEOLOGY
}

\author{
JON ERLANDSON ${ }^{1}$, RUDY WALSER ${ }^{2}$, HOWARD MAXWELL ${ }^{2}$, NANCY BIGELOW ${ }^{2}$ \\ JOHN COOK $^{3}$, RALPH LIVELY ${ }^{4}$, CHARLES ADKINS $^{2}$, DAVE DODSON ${ }^{2}$ \\ ANDREW HIGGS ${ }^{2}$ and JANETTE WILBER ${ }^{2}$
}

Between the Alaska Range to the south and the Brooks Range to the north, the Yukon River and its tributaries form an extensive network of waterways leading through the lowlands of interior Alaska deep into the North American continent (Fig 1). Despite the extremely cold winters of this arctic and subarctic landscape, much of the region remained unglaciated during the last 50,000 years. The central Alaskan lowlands are at the west end of the "ice-free corridor," thought by most prehistorians to be the pathway to the Americas for Asian hunter-gatherers crossing the continental Beringian "landbridge." Until recently, relatively little was known of the early human prehistory of Alaska's interior. Growing interest in the timing, nature and paleoecological context of the initial peopling of the Americas has prompted excavation at a number of early sites in central Alaska and the adjacent Yukon (see Powers \& Hamilton 1978; West 1981; Fagan 1987: 119-134; Hamilton 1989; Powers \& Hoffecker 1989).

Despite the accumulation of archaeological data, defining a regional cultural chronology for interior Alaska is difficult. Many key sites contain multiple components in shallow and poorly stratified sediments mixed by natural and cultural processes (Hamilton 1989). Lying within a zone of discontinuous permafrost, archaeological sites of interior Alaska are particularly prone to mixing by cryoturbation. In most sites, poor preservation of organic remains makes it difficult to recover adequate samples for ${ }^{14} \mathrm{C}$ dating. Problems in interpreting site chronologies are exacerbated by periodic wildfires that burn plant remains on and below soil surfaces, depositing naturally derived charcoal in cultural strata.

Recent excavations in the Nenana Valley south of Fairbanks have explored several wellstratified archaeological sites that provide new insight into the early prehistory of Alaska's interior (eg, Powers \& Hamilton 1978; Hoffecker 1985; Maxwell 1987; Powers \& Hoffecker 1989). Data from these stratified sites can be used to evaluate radiocarbon and artifact-based chronologies proposed for many of the poorly stratified sites of the region. In this paper, we present ${ }^{14} \mathrm{C}$ dates from two major sites of the Alaskan Interior that contain typological evidence for occupation spanning much of the Holocene: Chugwater (FAI-035) and Healy Lake Village (XBD-20). Research at each site produced an extensive suite of ${ }^{14} \mathrm{C}$ dates that are unpublished, described incompletely, or available only in technical reports with limited distribution (eg, Cook 1969; Maitland 1986; Lively 1988). Our goals are to make contextual data accessible to a wider range of scholars interested in the peopling of the New World, to describe some of the problems inherent in dating and interpreting such sites, and to examine some broader implications of recent research at early central Alaskan sites.

The dates described here were analyzed by five laboratories: Beta Analytic, Inc (Beta), Geochron Laboratories, Inc (GX), the University of Alaska (AU), the AMS Group in Zurich (ETH) and DICARB Radioisotopes Laboratory (DICARB). Three additional Healy Lake Village samples

\footnotetext{
${ }^{1}$ Department of Anthropology, University of Oregon, Eugene, Oregon 97403

${ }^{2}$ Department of Anthropology, University of Alaska, Fairbanks, Alaska 99775

${ }^{3}$ Bureau of Land Management, 1150 University Ave, Fairbanks, Alaska 99709

${ }^{4}$ Tongass National Forest, 204 Siginaka Way, Sitka, Alaska 99835
} 
were analyzed at the Smithsonian Laboratory as interlaboratory checks and have been listed elsewhere (Stuckenrath \& Mielke 1973). Two other Healy Lake Village samples were analyzed at Gakushuin University and listed by Kigoshi, Suzuki and Fukatsu (1973). Previously listed dates are not described here, although they are referenced where appropriate.

Laboratory pretreatment and analysis procedures varied, but generally included cleaning and physical separation of macroscopic contaminants (rootlets, etc), followed by alternating $\mathrm{HCl}$ and $\mathrm{NaOH}$ rinses to remove extraneous carbonates and humic acids. Accelerator Mass Spectrometry (AMS) dates were corrected for the isotopic effects of natural and laboratory processes, but conventional dates apparently were not. Where laboratory reports indicate variation from normal pretreatment or analytical techniques, these have been noted in the comments for individual dates. More specific data on the processing, pretreatment and counting techniques of each lab can be found in previous date lists (Krueger \& Weeks 1966; Sumodi 1974; Reeburgh \& Young 1976; Erlandson 1988).

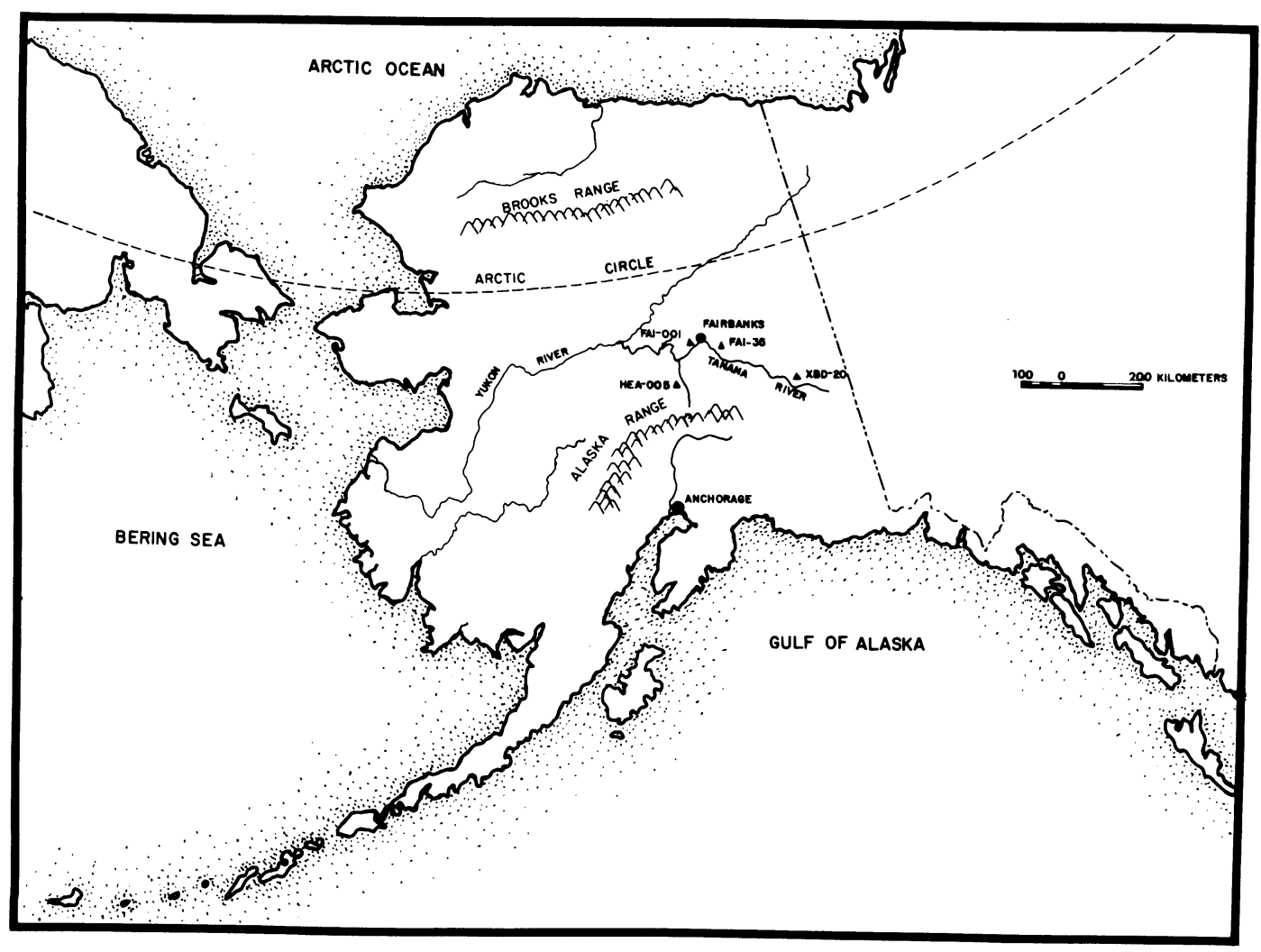

Fig 1. Regional setting of the study area 


\title{
ARCHAEOLOGIC SAMPLES
}

\author{
United States
}

Alaska

\section{Chugwater Site (FAI-35) series}

Samples of charcoal and sedimentary organics obtained from a large $(100 \times 165 \mathrm{~m})$ site on the east summit of Moose Creek Bluff $\left(64^{\circ} 43^{\prime} 30^{\prime \prime} \mathrm{N}, 147^{\circ} 13^{\prime} 05^{\prime \prime} \mathrm{W}\right)$ near the town of North Pole, $25 \mathrm{~km}$ southeast of Fairbanks (Fig 1). The bluff reaches an elevation of $245 \mathrm{~m}$ asl, ca $100 \mathrm{~m}$ above the lowlands between the Chena and Tanana Rivers. Moose Creek Bluff is the site of the only pictographs documented in interior Alaska (Giddings 1941). The Chugwater site (FAI-35) was recorded in 1975 by JP Cook and listed on the National Register of Historic Places in 1979. Several field studies have taken place at the site. Those sponsored by the Army Corps of Engineers (ACE) in 1982 and 1983 (Maitland 1986) and by the University of Alaska Fairbanks (UAF) from 1984 to 1986 (Aigner \& Lively 1986; Lively 1988) excavated about 400m² (ca 2.4\%) of the site deposits and produced the ${ }^{14} \mathrm{C}$ dates and related data reported here.

FAI-35 contains multiple occupational components that, to some extent, are horizontally and vertically discrete, though overlapping and mixed by postdepositional and historic site modifications. Strata in some areas contain artifacts diagnostic of much of the past 11,000 years of prehistory in sediments averaging $30 \mathrm{~cm}$ deep, and seldom exceeding $50 \mathrm{~cm}$. Lively (1988) identified three separate components: Component 1, a basal non-microblade level with teardropshaped (Chindadn) bifaces and small endscrapers similar to Nenana Valley assemblages antedating 10,600 BP (Powers \& Hoffecker 1989); Component 2, a microblade-bearing level with asymmetric bifacial points or knives attributed to the early Denali complex or American Paleoarctic tradition (APT); and Component 3, an upper microblade-bearing level with notched and lanceolate points typical of Tuktu or Late Denali sites of the interior. Maitland (1986: 115) also attributed several artifacts in the upper levels to an incursion or influence by Norton peoples.

Beta-7567. Northeast site area

Modern

Small charcoal fragments from $35-45 \mathrm{~cm}$ below datum (BD) ${ }^{5}$ in Feature 5, Square N19/E73. Coll July 1983 by R Lively, subm Sept 1983 by G Reynolds, ACE.

Comment (CA): Maitland (1986: 29) described Feature 5 as a scatter of charcoal possibly "blown, washed, or somehow moved from hearths, or it might be from forest fires." Modern date suggests a natural origin for charcoal.

Beta-7636. West site area

$160 \pm 70$

Sedimentary organics in Feature 1, 40-43cm BD in Square S0/W85. Coll Sept 1982 by M Roe, subm Sept 1983 by G Reynolds.

Comment (JE/CA): Maitland (1986: 30) described Feature 1 as a saucer-shaped hearth ca $1 \mathrm{~m}$ wide. A second sample from this square also was dated (Beta-7637), but field notes, sample data sheets and technical report are unclear about the exact provenience or context of either sample.

\footnotetext{
${ }^{5}$ Depth measurements for the Chugwater samples were taken from a datum at ground surface of the NW corner of each test unit. Due to the sloping ground surface in many test locations, these measurements often do not reflect sample depth below surface accurately. Consequently, the Chugwater dates plotted in Figure 2 could not be arranged by depth.
} 
Beta-9247. Southeast site area

Scattered charcoal from a $35 \times 80 \mathrm{~cm}$ area of Feature 2, 52-54cm BD in Square S3/E59. Maitland (1986: 30) described Feature 2 as a basin-shaped hearth, $50 \mathrm{~cm}$ wide, dug to a depth of $25 \mathrm{~cm}$ from the upper levels of the site. Contents of feature were a purplish sediment rich in ash and charcoal. Coll Sept 1982 by RE Maitland, subm April 1984 by G Reynolds.

Comment (JE/CA): small sample given extended counter time to reduce statistical error. This is 1 of 5 widely discordant dates (see Beta-9248 [950 \pm 100 ], -9249 [840 \pm 90 ], -9250 [1120 \pm 90 ] and 9251 [2370 \pm 80$]$, all below) from Feature 2 .

Beta-7637. West site area

$720 \pm 60$

Sedimentary organics from Feature 1 sediments $40-43 \mathrm{~cm}$ BD in Square S0/W85. Coll Sept 1982 by M Roe, subm Sept 1983 by G Reynolds.

Comment (CA/JE): date significantly antedates companion sample (Beta-7636 [160 \pm 70$]$, above) from same square. Because of uncertainty over context of samples, Maitland (1986: 30) referred to both dates as "rather meaningless," but speculated that the earlier date may be most accurate.

Beta-9249. Southeast site area $840 \pm 90$

Charcoal from $25-41 \mathrm{~cm} \mathrm{BD}$, just outside of Feature 2 in Square S2/E60. Coll Sept 1982 by J Goodfellow from area 25 x 100cm wide, subm May 1984 by G Reynolds.

Comment (CA/JE): sample analyzed by AMS. Charcoal concentration in relatively dense scatter of chipped stone artifacts, but may include charcoal from both cultural and natural sources (Maitland 1986: 31).

Beta-7565. Southeast site area $870 \pm 50$

Charcoal from $31-34 \mathrm{~cm} \mathrm{BD}$ in Square S2/E58. Coll June 1983 by R Lively from area $4 \mathrm{x}$ $26 \mathrm{~cm}$ wide in ephemeral concentration ("Feature 3"). Subm Sept 1983 by G Reynolds.

Comment (AH): sample may be assoc with Feature 2, which produced similar date (Beta-9248 [950 \pm 105 ], below). According to Maitland (1986: 32), this and roughly synchronic dates are assoc with a period of loess deposition.

\section{Beta-9248. Southeast site area}

$950 \pm 100$

Charcoal from $54 \mathrm{~cm} \mathrm{BD}$, outside Feature 2 in Square S3/E59. Coll Sept 1982 by RE Maitland, subm May 1984 by G Reynolds.

Comment (JE/AH): small sample AMS-dated; some confusion about square that sample came from exists in field notes and data sheet. Date is consistent with Beta-7565 (870 \pm 50$)$, supporting spatial and temporal association of two samples.

Beta-9245. Northwest site area

$1000 \pm 100$

Charcoal from base of humus layer 37cm BD in Square N11/W70. Coll Sept 1982 by RE Maitland, subm May 1984 by G Reynolds.

Comment (AH/JE): small sample AMS-dated. Maitland (1986: 32) does not relate sample to a feature, natural or cultural, and states that no artifacts were recovered in level or square. It is unclear if this date has any cultural assoc or significance. 
Beta-9250. Southeast site area

$1120 \pm 90$

Charcoal flecks from $30-38 \mathrm{~cm}$ BD in Square S2/E60. Sample from area $20 \times 30 \mathrm{~cm}$ wide outside Feature 2, but Maitland (1986) suggests a possible assoc with Feature 4, ca $6 \mathrm{~m}$ away. Coll Sept 1982 by J Goodfellow, subm April 1984 by G Reynolds.

Comment (AH/JE): small sample given extended counter time to reduce error. Identical dates for Beta-9250 and Beta-7566 may suggest a non-cultural origin for both samples and features.

\section{Beta-7566. Southeast site area}

$1120 \pm 90$

Three chunks of solid charcoal from Feature 4, 46-47cm BD in Square S7/E64. Coll July 1983 by R Lively, subm Sept 1983 by G Reynolds. Feature 4 was a trough-shaped charcoal concentration assoc with orange sediments, $31 \times 42 \mathrm{~cm}$ wide, extending from $42-53 \mathrm{~cm}$ BD into decaying bedrock.

Comment (AH/JE): sample given extended counter time to reduce error. Artifacts (eg, teardropshaped biface) from square are typical of Chindadn complex artifacts at Healy Lake Village (Cook 1969), dating to ca $10,000 \mathrm{BP}$. This feature evidently is intrusive, assoc either with later site occupation or a natural wildfire.

Beta-9246. Southeast site area

$1320 \pm 80$

Charcoal from area $9 \times 16 \mathrm{~cm}$ wide in Feature 6, a charcoal scatter of uncertain origin, 36-40cm BD in Square S5/E62. Coll July 1983 by R Lively, subm April 1984 by G Reynolds.

Comment (HM/JE): small sample AMS-dated. According to Maitland (1986: 29), this sample was not assoc with a visible pit or sedimentary discoloration and may be redeposited from natural or cultural contexts. Microblades, side-notched point base and debitage found in same general area, but no temporal association of these with date is possible.

Beta-15115. West site area

$1720 \pm 90$

Charcoal from $31 \mathrm{~cm}$ BD in NE corner of Square S5/W38. Coll July 1985 by E Kjellgren, subm 1986 by R Lively.

Comment (AH): artifacts (microblades and flakes) found in same level, but no direct assoc with date is possible.

Beta-15116. West site area

$2020 \pm 100$

Charcoal from Square S2/W43. Coll 1984-85 by K Burning, subm 1986 by R Lively.

Comment (JE): assoc of sample is unclear. Charcoal may be of natural origin.

Beta-9252. Southeast site area

$2300 \pm 70$

Charcoal from $30-34 \mathrm{~cm}$ BD in Square S3/E64. Coll June 1983 by R Maitland, subm April 1984 by G Reynolds.

Comment (JE): sample appears to have been isolated, not assoc with any concentration of charcoal.

Beta-9251. Southeast site area

$2370 \pm 80$

Charcoal from area $15 \times 20 \mathrm{~cm}$ wide in Feature 2, 60-68cm BD in Square S2/E59. Coll Sept 1982 by J Goodfellow, subm May 1984 by G Reynolds. 
Comment (HM/JE): small sample AMS-dated. Side-notched point and numerous pieces of debitage in same excavation square, though none assoc directly with sample. Upper $10 \mathrm{~cm}$ of stratigraphic profile disturbed by recent earthmoving activity.

Beta-9253. Southeast site area

$2530 \pm 110$

Charcoal from 28cm BD in Square S3/E64. Coll June 1983 by RE Maitland, subm April 1984 by $G$ Reynolds.

Comment (HM/JE): sample appears to have been isolated, not assoc with any concentration of charcoal. Two microblade fragments and miscellaneous debitage found in square.

Beta-7570. Southwest site area

$6260 \pm 390$

Charcoal from area $10 \times 15 \mathrm{~cm}$ wide in Feature 7, 54-61 cm BD in Square S19/W10. Coll Aug 1983 by P Ivie, subm Sept 1983 by G Reynolds.

Comment (JE/HM): small sample from possible hearth given extended counter time to reduce error.

Beta-7569. Southwest site area

$7760 \pm 130$

Charcoal from SW corner of Square S19/W9, from 55cm BD in Feature 7. Coll Aug 1983 by P Ivie, subm Sept 1983 by G Reynolds.

Comment (HM/JE): small sample from possible hearth AMS-dated. Date varies significantly from Beta-7570 suggesting some mixing of charcoal within feature.

Beta-18509/ETH-2606. North site area

$8960 \pm 130$

Charcoal from 68cm BD in Square N12/W26. Coll Sept 1986 by R Lively, subm Nov 1986 by R Lively.

Comment (HM/JE/AH): very small sample AMS-dated. A bifacial tool and chalcedony flake were found at the same general level of square. Lively (1988) believes this date and Beta-19498/ ETH-2742 (9460 \pm 130$)$ are assoc with and accurately reflect the age of the Component II (Denali) occupation at Chugwater.

Beta-19498/ETH-2742. North site area

$9460 \pm 130$

Charcoal from 59cm BD in Square N11/W26. Coll Aug 1986 by R Lively, subm Jan 1987 by R Lively.

Comment (HM/JE/AH): very small sample AMS-dated. Microblade and flakes found in same level of square. Date consistent with known antiquity of Denali complex sites in interior Alaska.

General Comment: despite a suite of 20 dates, much of the absolute chronology for the Chugwater site remains problematic. Major gaps remain (Fig 2), eg, there are no dates for the earliest component, and incomplete definition for Component 3. Moreover, the context of the dated samples leaves much ambiguity about the meaning of the ${ }^{14} \mathrm{C}$ dates. It is conceivable that all the dated samples are of non-cultural origin or are a mixture of natural and cultural organics. Indications of past forest fires in interior Alaska and postdepositional modifications of the Chugwater sediments by cryoturbation, bioturbation and prehistoric and historic human activity leads us to view most of the Chugwater dates with caution. Penetration of the shallow sediments 


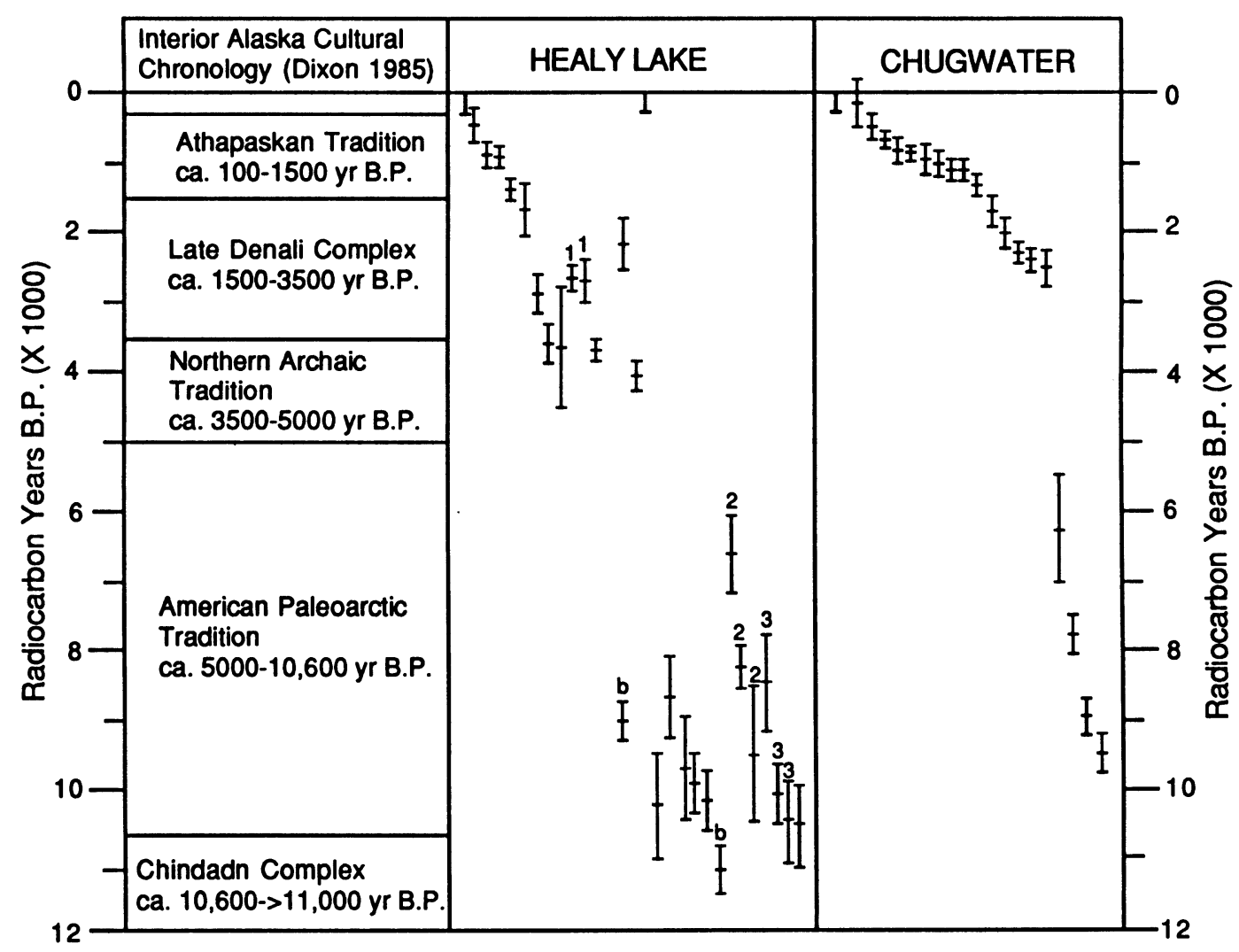

Fig 2. Chronological comparison of Healy Lake and Chugwater dates in relation to regional cultural sequence (Dixon 1985). Healy Lake dates (including Gak and SI dates) are plotted by increasing depth: bone dates = b; sample splits = 1 , 2, 3. Chugwater dates plotted by increasing age only. All date ranges are at 20 .

by a dense root mat appears to be an especially serious source of mixing at Chugwater (see Aigner \& Lively 1986).

Reviewing the chronological implications of the dates, Lively (1988: 76) concluded that the Chugwater chronology still is based largely on comparison with similar dated assemblages in central Alaska:

The widespread occurrence of root burn throughout the site and the ephemeral nature of possible hearths make most individual ${ }^{14} \mathrm{C}$ samples unreliable. Some grouping of sample dates occurs between 500-1300 BP (9), $1700-2500 \mathrm{BP}(5)$, and two dates between 6200 and $7800 \mathrm{BP}$, but in general there is no correlation between dates and depth below surface. None of these dates can be clearly associated with diagnostic materials (Lively 1988: 76).

Lively confidently correlated diagnostic artifacts with two early Holocene dates associated with Denali (or early American Paleoarctic) tools in Component 2 sediments. Even these dates, based on AMS dating of single charcoal fragments, should be interpreted cautiously since they have not been related to cultural features. At best, they should be taken as rough estimates of the date of deposition for the Component 2 sediments and only general indicators of the age of the artifacts found therein. 
At Chugwater, interpretation of many of the ${ }^{14} \mathrm{C}$ dates is complicated by collection procedures that relied on standard dating of large samples from scattered and finely comminuted "concentrations" of charcoal of uncertain origin. The ambiguity of some of these charcoal "features" is clear from Maitland's (1986: 30-31) description of one of them (Feature 2), from which five dates span almost 2000 years:

\footnotetext{
There is a cluster of 5 dated samples from the four squares at the intersection of which the hearth lies. They are all taken from scatters of charcoal where these were particularly concentrated. The concentrations were up to $20 \mathrm{cms}$ wide and several centimeters thick. While it was appreciated at the time that the samples were taken that they might not all belong to the same event, and that cross-contamination could occur, it was necessary to collect over such areas to get enough material for any kind of dating at all (emphasis added).
}

Under such circumstances, the collection and submission of individual charcoal fragments for AMS dating might have resulted in less ambiguous radiocarbon dates.

Despite the large number of ${ }^{14} \mathrm{C}$ dates, the Chugwater chronology relies heavily on the presence of temporally diagnostic artifacts, their position within the site and comparisons to similar assemblages of interior Alaska. Typologically, the artifacts also suggest a probable terminal Pleistocene use of the site. The distribution of temporally diagnostic artifacts led Lively to define three components at the Chugwater site. Component 1 corresponds generally to the Chindadn complex, as defined by Cook (1975) and Dixon (1985), and the Nenana complex (Powers \& Hoffecker 1989), dated between 10,600 and 11,500 BP. Artifacts from the basal levels at Healy Lake Village, Dry Creek (HEA-5), Walker Road (HEA-130) and other sites are typologically similar to Component 1 at Chugwater. Diagnostics include small teardrop-shaped and triangular bifaces, "Paleoindian" end scrapers, large side scrapers and a general absence of burins and microblades.

Component 2 is defined by the two oldest Chugwater dates and comparisons with typologically similar Denali (or APT) assemblages at numerous sites throughout the interior, dated between 10,000 and 7000 BP (West 1975, 1981). The Chugwater dates for charcoal fragments in the sediments containing Denali artifacts suggest a Component 2 occupation sometime between 8000 and 10,000 BP. Artifacts from this component include microblades and wedge-shaped microblade cores, burins and small bifaces.

Component 3 is defined primarily by intersite artifact comparisons, although a few of Maitland's (1986) ${ }^{14} \mathrm{C}$ dates may have valid cultural associations. The upper component produced artifacts diagnostic of several archaeological complexes, including Tuktu (Campbell 1961), Northern Archaic (Anderson 1968) and the enigmatic Late Denali (Dixon 1985). These cultural manifestations are thought to span the period from ca 5000 to $1000 \mathrm{BP}$. Artifacts from this component include microblades, several microblade core types, side- and corner-notched points, lanceolate points and shaft smoothers. Some of the Chugwater lanceolate points are similar superficially to coastal forms of the Norton culture (Giddings 1964), although such general similarities may result from a diffusion of technology and ideas rather than migration of people.

\section{Healy Lake Village (XBD-20) series}

Charcoal, sediment and bone samples from a large historic and prehistoric site located on a bedrock ridgespur on the NE shore of Healy Lake $\left(64^{\circ} \mathrm{N}, 144^{\circ} 45^{\prime} \mathrm{W}\right)$, ca $200 \mathrm{~km} \mathrm{SE}$ of Fairbanks and $50 \mathrm{~km}$ E of Delta Junction, Alaska (Fig 1). The site lies $3 \mathrm{~m}$ above the maximum elevation of Healy Lake $(343 \mathrm{~m})$, formed by backflow from the Tanana River at its confluence with the Healy River $5 \mathrm{~km} \mathrm{NW}$ of the site. XBD-20 was tested by R McKennan in 1962, with more extensive excavations by Cook and McKennan in 1966, and by Cook from 1967 to 1972 (Cook 1969, 1989). A total of ca $400 \mathrm{~m}^{2}$ was excavated in 176 pits ca $1.5 \mathrm{~m}$ wide $\left(5^{\prime} \times 5^{\prime}\right)$, roughly $20 \%$ of the site area 
(Cook 1989). Pits were dug in arbitrary levels $5 \mathrm{~cm}$ (2") thick, starting at the base of an organic root mat that contained historic materials. All samples from Healy Lake Village were submitted by J Cook between 1968 and 1973.

Artifacts diagnostic of several occupational components spanning as much as 11,000 years were found in an unconsolidated aeolian sand and loess deposit ca $60 \mathrm{~cm}$ thick. Soil horizons, clay bands, and other "post-depositional" features are evident in this aeolian unit (Hamilton 1989), but the strata are disturbed to some extent by frost heave, animal burrowing, tree throws, root growth, trampling and cultural modifications. Moreover, the site strata undulate, so some materials from different strata may be found in the same arbitrary level and vice versa.

Based on his early research at XBD-20 and a preliminary suite of four ${ }^{14} \mathrm{C}$ dates, Cook (1969: 254) defined four prehistoric cultural components, including: 1) a basal Early horizon (Levels 6-10), later referred to as the Chindadn complex (Cook 1975), with microblades, wedge-shaped microblade cores, burins and occasional teardrop and small triangular points; 2) a Quartzite horizon (Levels 4 \& 5) with large scrapers, small endscrapers and few microblades; 3 ) a Tuktu horizon (Level 3) sharing affinities with Northern Archaic assemblages, including microblades, notched points and a de-emphasis of burin technology; 4) a prehistoric Athabaskan component (Levels 1 \& 2) with affinities to some Late Denali assemblages, including a diversified microblade technology, stemmed and notched points and burins.

GX-1945. Level 1

Modern

Small charcoal fragments from 0-5cm level of Square N15/W10. Coll July 1969 by H Kotani from bright reddish-brown area (possible hearth?).

Comment (RW/JE): very small sample limited precision of date. Lab noted that sample could not be distinguished from modern standard, but may date anytime within the last 300 years at 20 . Much of Level 1 in this square was disturbed by historic cultural activities.

\section{GX-2166. Level 1}

Charcoal from burned end of partially decomposed log in $0-5 \mathrm{~cm}$ level of Square N80/W40, just below historic cultural level. Coll July 1970 by S Fletter.

Comment (JE/DD): no artifacts noted in assoc, but date is consistent with others from Level 1. A third charcoal sample from Level 1 (Square N15/E10) dated to $900 \pm 90$ (Gak-1886), extending range of dates for this level, attributed to proto-Athabaskan occupation (Kigoshi, Suzuki \& Fukatsu 1973: 56).

\section{GX-2160. Level 2}

Wood and wood charcoal fragments from "firepit" in 5-10cm level of Square N80/W25. Coll July 1970 by S Hales. Hearth feature contained fire-cracked rock, and a cluster of burned animal bones (bird or small mammal?) was noted just to east.

Comment (JE/DD): clear cultural context and consistency with surrounding samples suggests that date accurately reflects age of feature and late prehistoric occupation. Four microblade fragments were found around feature in the same level, although some disturbance by frost-cracking was noted. 
GX-2168. Level 2

$1660 \pm 180$

Charred root material from $5-10 \mathrm{~cm}$ level of Square N85/W45. Coll July 1970 by R McKennan from a concentration of charcoal in soil.

Comment (DD/JE): lab notes indicate that an $\mathrm{NaOH}$ wash was not possible due to small sample size, but date is within range of other Level 2 dates.

GX-2169. Level 2

$2880 \pm 140$

Charcoal fragments from $6-13 \mathrm{~cm}$ level of Square N70/E5. Coll June 1970 by J Steenblik from area containing calcined bone, fire-cracked rock and fragments of moose (Alces alces) teeth.

Comment (DD): date falls within middle of range for other Level 2 samples.

GX-2165. Level 2

$3580 \pm 140$

Finely divided charcoal from $9-11 \mathrm{~cm}$ level of Square N25/E5. Coll 1969 by C Holmes.

Comment (NB/JE): lab notes indicate sample was too small for $\mathrm{NaOH}$ cleansing. Sample assoc with burin spall and microblades. Many pits and postholes noted in square, though none in immediate sample vicinity.

AU-?. $\quad$ Level 2

$3660 \pm 430$

Interlaboratory check sample of charcoal from same provenience as GX-2165, above.

Comment (NB/JE): date is referred to as AU-4 in some sources and as sample \#4 in lab notes, but does not correspond to AU-4 in Reeburgh \& Young (1976: 2). Lab notes indicate that charcoal was concentrated, although sample was too small for $\mathrm{NaOH}$ cleansing. Date is consistent with GX-2165, although no clear cultural assoc for either sample has been documented. A sixth charcoal sample from Level 2 (Square N25/W45) produced a date of $1360 \pm 80$ (Gak-1887) previously reported by Kigoshi, Suzuki \& Fukatsu (1973:56) and is consistent with range of others from level.

GX-2176. Level 3

$2660 \pm 100$

Charcoal fragments from 10-15cm level of Square N45/E10. Coll 1969 by J Cook, combining charcoal from two discrete patches in square, one $15 \mathrm{~cm}$ deep, the other between 11 and $13 \mathrm{~cm}$ deep.

Comment (RW/JE): date should be an average age for two charcoal concentrations. A core tablet and lanceolate projectile point were found in this level.

\section{DICARB 3065. Level 3}

$2680 \pm 150$

Charcoal fragments from $11 \mathrm{~cm}$ level of Square N35/E35. Coll Aug 1970 by S Fletter from red-brown loess deposit. Charcoal appears to be assoc with accumulation of fire-cracked rock.

Comment (RW): no lab report is available for sample, so pretreatment and analytical methods are uncertain. Precise location of sample in square is uncertain, since reported coordinates do not match map in field notes. 
DICARB-3064. Level 3

$3710 \pm 70$

Scattered charcoal fragments in sedimentary matrix from $10-15 \mathrm{~cm}$ level of Square N30/W0. Coll June 1969 by E J Dixon. Sample assoc with clusters of burned bone fragments and burned rocks extending from Level 3 into overlying Level 2.

Comment (JE/RW): date is consistent with sample from underlying level of same square (GX-2163, below) and context suggests that date is assoc with cultural activity.

\section{GX-2161. Level 4}

$2150 \pm 180$

Charcoal fragments from $17 \mathrm{~cm}$ level in gray-brown loess in Square N40/E15. Coll Aug 1969 by R McKennan from narrow strip of "fairly pure charcoal" extending for $38 \mathrm{~cm}$ at $17 \mathrm{~cm}$ level. No artifacts found in direct assoc.

Comment (RW): small sample size limited precision of analysis.

GX-2163. Level 4

$4010 \pm 110$

Charcoal fragments from $15-20 \mathrm{~cm}$ level of Square N30/W0. Coll June 1969 by E J Dixon from scatter of charcoal and bone fragments extending across entire square. According to field notes, burned area extends into underlying levels 5, 6 and 7 .

Comment (RW/JE): date is consistent with DICARB-3064 from overlying level in same square. Due to lack of assoc artifacts, cultural assoc of dispersed charcoal is uncertain.

GX-1340. Level 4

$8960 \pm 150$

Apatite from burned bones (primarily bird) from NE portion of $15-20 \mathrm{~cm}$ level of Square N15/E0. Coll 1967 by J Cook from "extensive hearth" from which only $1.5 \mathrm{~g}$ of charcoal was retrieved.

Comment (JE/JW): lab notes indicate bone was cleansed in dilute $\mathrm{HCl}$, then dissolved in $\mathrm{CaCO}_{3}$ to purify apatite via hydrolysis. Date is stratigraphically anomalous, and sample context suggests it was not intrusive from lower levels. Given susceptibility of bone apatite to contamination, the accuracy of the date is questionable.

GX-2162. Level 5

Modern

Charcoal fragments from $19-23 \mathrm{~cm}$ level of Square N20/E25. Coll June 1969 by J Cook.

Comment (RW/JE): date is stratigraphically anomalous, with reported count rate higher than modern standard. Sample appears to have been intrusive, possibly related to recent forest fire and root burning.

\section{GX-2173. Level 6/7}

$10,250 \pm 380$

Organic matter in sediment from $31 \mathrm{~cm}$ level of Square N90/W40. Coll Aug 1970 by J Cook, from thin $(0.5-2 \mathrm{~cm}$ thick) layer containing microblade and fish scales.

Comment (DD/JE): lab notes indicate charcoal was too fine to separate from sedimentary matrix, so entire sample was digested in hot $\mathrm{HCl}$ and roasted in pure oxygen to recover organics. Sample assoc and consistent with interlaboratory check samples, AU-7, GX-2174, below, and SI-737 (Stuckenrath \& Mielke 1973: 405). 
GX-2171. Level 7

$8660 \pm 280$ Gilmour.

Organic matter in sediment from 31-36cm level of Square N25/E25. Coll 1969 by D

Comment (JE): according to lab notes, whole sample was digested in hot dilute $\mathrm{HCl}$ to remove carbonates then roasted in oxygen to recover organic carbon.

\section{GX-2170. Level 7}

$8680 \pm 240$

Finely divided charcoal and organic material in sediment from $31-36 \mathrm{~cm}$ level of Square N70/E5. Coll Aug 1970 by J Steenblik.

Comment (JE): lab notes indicate organic material could not be concentrated, so entire sample was digested in hot $\mathrm{HCl}$ and roasted in pure oxygen to recover organics. Date consistent with others from level.

\section{AU-7. Level 7}

$9640 \pm 370$

Finely divided charcoal in sedimentary matrix with many tiny rootlets. Bulk sample from entire $31-36 \mathrm{~cm}$ level of Square N90/W40. Coll July 1970 by J Cook from $0.5-2 \mathrm{~cm}$ thick charcoal-rich lens undulating across several test squares and possibly assoc with forest fire. No diagnostic artifacts assoc with sample, although three fish scales were recovered from horizon, and layer was attributed to the Chindadn complex.

Comment (JE/NB): according to lab notes, several preliminary runs $(9370 \pm 190,9230 \pm 210$, $9130 \pm 240)$ were made on this sample during calibration of equipment. The earlier date was regarded by lab personnel as most accurate, although all are statistically similar.

\section{GX-2174. Level 7}

$9900 \pm 210$

Interlaboratory check from same provenience as AU-7.

Comment (NB/JE): lab notes indicate that finely divided charcoal could not be concentrated, so entire sample was digested in hot $\mathrm{HCl}$ to remove carbonates. Date is consistent with AU-7 and a third interlaboratory check sample (SI-737) that produced a charcoal date of $10,150 \pm 210$ (Stuckenrath \& Mielke 1973: 405). Average age of four samples from charcoal-rich lens is 10,010
BP.

\section{GX-1341. Level 8}

Bone apatite from aggregate of scattered rodent (?) bones assoc with possible hearth feature in $36-41 \mathrm{~cm}$ level of Square N45/W0. Coll 1967 by J Cook. No diagnostic artifacts assoc with feature, which extends through Levels 7,8 and possibly 9.

Comment (RW/JE): lab notes indicate too little collagen remained in bone to produce accurate date. Correspondence suggests some confusion about correlation of this sample with GX-1340.

\section{AU-8. Level 9}

$9400 \pm 530$

Brown soil with scattered organic material or charcoal flecks from $43-53 \mathrm{~cm}$ level of Square N110/W80. Coll 1970 by R Jordan.

Comment (JE/NB): no diagnostic artifacts were assoc with sample. An interlaboratory check 
sample (SI-738) from same provenience dated to $8210 \pm 155$ (Stuckenrath \& Mielke 1973: 405), within $2 \sigma$ of $\mathrm{AU}-8$.

GX-2159. Level 9

$6650 \pm 280$

Interlaboratory check sample from same provenience as AU-8 and SI-738.

Comment (NB/JE): lab notes indicate sample not concentrated or cleansed in $\mathrm{NaOH}$. Date does not correlate with interlaboratory check samples and may be contaminated by recent organics.

\section{GX-2175. Level 10}

$8470 \pm 360$

Organic material from brown sediment in 51-58cm level of Square N65/E10. Coll June 1970 by S Hales from "small pit" ca $76 \mathrm{~cm} \times 82 \mathrm{~cm}$ wide and $13 \mathrm{~cm}$ deep. Nearest artifactual material at $41 \mathrm{~cm}$ level, including fire cracked rock and undiagnostic stone artifacts.

Comment $(\mathrm{NB} / \mathrm{JE})$ : lab notes indicate sample not concentrated or cleansed in $\mathrm{NaOH}$. Interlaboratory check sample (SI-739) from same provenience dated to $10,040 \pm 210$ (Stuckenrath \& Mielke 1973: 405).

\section{AU-6. Level 10}

$10,430 \pm 280$

Interlaboratory check sample from same provenience as GX-2175 and SI-739.

Comment (JE): date suggests GX-2175 may have been contaminated by recent organics and age of pit feature may be ca 10,240 BP, an average of AU-6 and SI-739.

\section{GX-1944. Level 10}

$10,500 \pm 280$

Finely divided charcoal in sediment from "charcoal smears in soil" in Square N60/E5. Coll June 1969 ? . by J Cook from rectangular pit, $51 \mathrm{~cm} \mathrm{x} 71 \mathrm{~cm}$ wide, with maximum depth at $62 \mathrm{~cm}$. No artifacts assoc with pit, but two fragments of mammal bone (caribou?) were noted in it.

Comment (RW/JE): according to lab notes, fine hairlike rootlets could not be picked or floated from sample, nor could charcoal be concentrated for analysis. Entire sample was processed, which may underestimate sample age.

General Comment: Cook's (1969) generalized stratigraphic and cultural sequence for Healy Lake Village was based on four stratigraphically ordered ${ }^{14} \mathrm{C}$ dates spanning the past 11,100 years. With additional excavation and a total of 28 dates now available (Fig 2), the situation is more complex than initially thought. Level 2 , originally attributed to a proto-Athabaskan occupation, has produced dates with midpoints ranging from 900 to $3650 \mathrm{BP}$. Level 3, attributed to the Tuktu horizon, produced a single date of $2660 \mathrm{BP}$, while Levels $4 \& 5$ (the Quartzite horizon) have midpoints ranging from modern to 8960 BP. The lowest levels (6-10), related by Cook (1969, 1975 ) to the Early horizon or Chindadn complex, produced widely divergent dates with midpoints ranging from 6650 to $11,090 \mathrm{BP}$.

Though the recovered artifacts compare favorably with some of the ${ }^{14} \mathrm{C}$ dates, the combined effects of bioturbation, cryoturbation, periodic wildfires, occupational trampling and other cultural modifications on the shallow site deposits inhibit interpretation of the cultural sequence. This problem is exacerbated by undulating strata sometimes crosscut by arbitrary excavation levels, the small size of some dated samples, variation in the processing techniques of different laboratories, and dating of materials now known to be susceptible to contamination (ie, bone apatite) or imprecision (ie, soil organics). 
Discrepancies between the interlaboratory check samples illustrate some of the problems with variation in lab processing, small sample size, sample contamination and chronological interpretation. Three samples, one each from Levels 7, 9 and 10 were split between labs for dating. Many of these dates have relatively large errors and overlap at $2 \sigma$, but the range of the splits from Levels 9 and 10 still are separated by over 1100 years and almost 600 years, respectively. It seems likely that the two youngest dates in these splits were contaminated by younger carbon (rootlets, etc) removed incompletely during pretreatment.

Omitting clearly anomalous dates such as GX-1340 (8960 \pm 150$),$ GX-2159 (6650 \pm 280$)$, GX-2162 (modern) and GX-2175 (8470 \pm 360$)$, an uncritical interpretation of the Healy Lake series suggests: 1) relatively intense occupation during the terminal Pleistocene and early Holocene; 2) a hiatus or reduction in occupation between ca 8000 and 4000 BP; 3) re-occupation during the late Holocene by Northern Archaic and Late Denali groups; possibly leading to 4) use of the site by ancestors of the historic Athabaskan residents of the village.

A careful analysis of the context of the dated samples and the formation processes that have affected the archaeological record, however, suggests an alternative interpretation. For instance, it is not clear that occupational intensity declined during the middle Holocene. The sediments that date to this time period are thin and have been disturbed by extensive cryoturbation. With reduced deposition, hearth charcoal or other cultural organics are less likely to be buried under sediments and preserved in the archaeological record. Finally, ongoing study by R Walser suggests that both sediments and artifacts have been mixed in the middle levels of the stratigraphic sequence, where the formation of frost polygons suggests extensive cryoturbation.

Despite problems associated with many of the XBD-20 dates, there is little doubt that a very early occupation occurred at Healy Lake. The nature and precise antiquity of that occupation remains controversial, however, partly because of the recognition of apparently pre-microblade (Nenana complex) components underlying microblade-bearing (Denali complex) levels at several Nenana Valley sites (Powers \& Hoffecker 1989) and the Chugwater site (Lively 1988). In the lowest levels at Healy Lake Village, attributed to the Chindadn complex (Cook 1975), elements of both the Nenana and Denali components are found together. While the oldest date (GX-1341) at Healy Lake Village has been questioned (Hamilton 1989) because of its material (bone apatite), the presence of teardrop-shaped (Chindadn) points, dated in excess of 11,000 years in stratified Nenana Valley sites, suggests that the initial occupation at Healy Lake indeed may antedate 11,000 $\mathrm{BP}$, regardless of the validity of the bone apatite dates. A number of dates from 8000 to 10,500 BP may indicate a Denali or early Paleoarctic occupation, possibly mixed by trampling and other processes with earlier Chindadn materials (Hamilton 1989). Alternatively, the lower levels of the site may reflect a transition between the Chindadn/Nenana complex and the Denali complex between 10,500 and $11,000 \mathrm{BP}$.

Also present at Healy Lake Village are dates associated with the Tuktu horizon (Campbell 1961) or Northern Archaic tradition (Anderson 1968), exemplified by the presence of distinctive notched points, and probably dated between ca 3500 and 4000 BP. Mixed in the same levels are artifacts (eg, microblades and microblade cores) sometimes attributed to the enigmatic "Late Denali" complex, an occupation probably dating between 1000 and 3500 BP at Healy Lake Village. Like the lower levels of the site, however, intermixing of artifacts in the shallow site sediments makes it difficult to separate elements of the Tuktu and Late Denali components and determine whether they are temporally discrete entities. The uppermost levels of the site postdate ca 1000 BP and appear to be related to proto-Athabaskan and historic Athabaskan Indian occupations (Cook 1969). 


\section{CONCLUSIONS}

The two ${ }^{14} \mathrm{C}$ series from Chugwater and Healy Lake Village illustrate several contextual and chronological problems that plague archaeological sequences in interior Alaska and around the world. Archaeologists and other prehistorians continue to underestimate the extent of interpretive problems caused by 1) the range and extent of formation processes that mix site deposits (Lynch 1990), 2) the persistence and nearly ubiquitous distribution of naturally deposited (and redeposited) charcoal in geological and archaeological sediments, 3) the incidental spatial association of bones, charcoal, artifacts and other materials with no temporal relationship, and 4) the extent to which natural processes (wildfires, stone fracture, bone modification, etc) can mimic cultural processes. Such problems may be especially severe at sites like Chugwater and Healy Lake Village with shallow unconsolidated sediments, where occupational trampling can move artifacts downward (see Gifford-Gonzalez et al 1985), and where lengthy occupation sequences may later be separated by secondary stratigraphic horizons formed after cultural deposition. A similar situation may exist at the Campus site (FAI-1) in Fairbanks, the type site for the Denali complex estimated by obsidian hydration to date to $8400 \mathrm{BP}$ (Bandi 1969: 52), where seven ${ }^{14} \mathrm{C}$ dates fall within the last 3500 years (Hamilton 1989: 12; Mobley 1990). Reviewing interpretive problems for early sites of the Americas, Lynch (1990: 29) concludes that "the greatest hazards are found in sand, loess, and other rather uniform but easily moved deposits where lack of obvious disturbance may lead the excavator to assume that there has been none. In that situation even intrusive pits can go unnoticed."

The ${ }^{14} \mathrm{C}$ dates from Chugwater and Healy Lake Village confirm the presence of multiple components at each site, but suggest that considerable mixing or other disturbance has occurred in the shallow sediments. The interpretation of the cultural sequence at both sites is complicated by the persistence of certain "diagnostic" artifacts (eg, microblades, wedge-shaped microblade cores), found as elements of many assemblages of interior Alaska dated from 10,500-1000 BP. Both sites also contain artifacts that appear to be diagnostic of pre-microblade components in the Nenana Valley. At Chugwater, such points reportedly are found below microblade-bearing levels (Lively 1988), supporting the notion of a bifacial pre-microblade cultural tradition. At Healy Lake Village, however, microblades were found in the same levels as Chindadn bifaces and other artifacts. Three explanations can account for the juxtaposition of these artifacts at Healy Lake Village: 1) temporally discrete Chindadn/Nenana artifacts have been mixed by frost heave, trampling, bioturbation and other processes; 2) the Chindadn levels may be transitional between the Nenana and Denali complexes of central Alaska; and 3) Nenana complex components are not "pre-microblade" sites, but functionally specific settlements of a culture combining both Denali and Nenana traits. Evidence from Japan, China, Siberia and other areas of the western North Pacific consistently indicate that leaf-shaped bifacial traditions precede microblade industries by one or more millennia (eg, Aikens \& Higuchi 1982: 326; Chang 1977). Evidence from Chugwater, the Nenana Valley sites and possibly southeast Alaska (Ackerman, Hamilton \& Stuckenrath 1979), suggests that the same sequence is found around the eastern North Pacific.

Finally, several authors (eg, West 1981; Dixon 1985; Fagan 1987; Powers \& Hoffecker 1989; Hamilton 1989) recently reviewed the early prehistory of eastern Beringia, concluding that there is no unimpeachable evidence for human occupation of the region prior to ca $12,000-15,000$ years ago. Alaska and the adjacent Yukon Territory are a vast region that may yet produce evidence for significantly earlier human occupation. As data continue to accumulate from early open-air and cave sites in a variety of coastal and interior environments, however, the lack of well-documented and securely dated sites antedating 11,500 BP is striking. As Hamilton (1989: 1) has pointed out, the lack of earlier archaeological sites in eastern Beringia presents a "troubling dilemma for those who accept a pre-Clovis age for the peopling of the Americas." 


\section{ACKNOWLEDGMENTS}

This paper would not have been possible without the technical reports of R Lively and RE Maitland, the notes of John Cook and the expertise of M Tamers and J Stipp of Beta Analytic, Inc. Chugwater dates submitted by $G$ Reynolds were funded by the ACE, those submitted by R Lively by a grant from the Geist Fund, University of Alaska Museum. Dates for Healy Lake Village were funded with support from the National Science Foundation and the National Museum of Canada. G Reynolds (ACE) kindly provided data associated with many of the Chugwater dates. Figure 1 was drafted by P Cheney, H Maxwell and J Erlandson, Figure 2 by $\mathrm{N}$ Bigelow. Finally, our thanks to JF Hoffecker, R Kra, R Jordan and O Mason, who reviewed an earlier draft of this paper and whose comments significantly improved the contents.

\section{REFERENCES}

Ackerman, RE, Hamilton, TD and Stuckenrath, R 1979 Early culture complexes on the northern Northwest Coast. Canadian Jour Archaeology 3: 195-209.

Aigner, JS and Lively, R 1986 Excavations at the Chugwater site, Alaska. Archaeology 39(6): 58-59, 76.

Aikens, CM and Higuchi, T 1982 Prehistory of Japan. New York, Academic Press, 356 pp.

Anderson, DD 1968 A Stone age campsite at the gateway to America. Scientific American 218(6): 24-33.

Bandi, HG 1969 Eskimo Prehistory. College, University of Alaska Press, 226 pp.

Campbell, JM 1961 The Tuktu complex of Anaktuvuk Pass. Anthropological Papers Univ Alaska 9: 61-80.

Chang, K 1977 The archaeology of ancient China. New Haven, Yale Univ Press, 535 pp.

Cook, JP (ms) 1969 The early prehistory of Healy Lake, Alaska. PhD dissert, Univ Wisconsin. 1975 Archaeology of interior Alaska. Western Canadian Jour Anthropology 3-4: 125-133.

1989 Historic archaeology and ethnohistory at Healy Lake, Alaska. Arctic 42: 109-118.

Dixon, EJ 1985, Cultural chronology of central interior Alaska. Arctic Anthropology 22(1): 47-66.

Erlandson, JM 1988 Cultural evolution and paleogeography on the Santa Barbara coast: a 9600 -year ${ }^{14} \mathrm{C}$ record from southern California. Radiocarbon 30(1): 25-39.

Fagan, BM 1987 The great journey: the peopling of ancient America. London, Thames and Hudson, 288 pp.

Giddings, JL 1941 Rock paintings in central Alaska. Am Antiquity 7(1): 69-71. 1964 The archaeology of Cape Denbigh. Providence, Rhode Island, Brown Univ Press, 331 pp.

Gifford-Gonzalez, DP, Damrosch, DB, Damrosch, DR, Pryor, J and Thunen, R 1985 The third dimension in site structure: an experiment in trampling and vertical dispersal. Am Antiquity 50(4): 803-818.

Hamilton, TD (ms) 1989 Late Pleistocene environments and peopling of eastern Beringia. Anchorage, Alaska, US Geol Survey.

Hoffecker, JF 1985 The Moose Creek site. National Geog Soc Research Reps 19: 33-48.

Kigoshi, K, Suzuki, N and Fukatsu, H 1973 Gakushuin natural radiocarbon measurements VIII. Radiocarbon 15(1): 42-67. Krueger, HW and Weeks, CF 1966 Geochron Laboratories, Inc radiocarbon measurements II. Radiocarbon 8: 142-160.

Lively, R 1988 A study of the effectiveness of a small scale probabilistic sampling design at an interior Alaskan site, Chugwater (FAI-035). US Army Corps of Engineers, Alaska district.

Lynch, TF 1990 Glacial-age man in South America? A critical review. Am Antiquity 55(1): 12-36.

Maitland, RE 1986 The Chugwater site (FAI-035), Moose Creek Bluff, Alaska, final report, 1982 and 1983 seasons. US Army Corps of Engineers, Alaska district.

Maxwell, H (ms) 1987 Archaeological research at Panguingue Creek site: an early Holocene overlook site in the Nenana Valley, Alaska. MA thesis (equivalent), Univ Alaska, Fairbanks.

Mobley, C 1990 The Campus site, a prehistoric camp at Fairbanks, Alaska. Fairbanks, Univ Alaska Press (in press).

Powers, WR and Hamilton, TD 1978 Dry Creek: A late Pleistocene human occupation in central Alaska. Occasional Papers 1: 72-77, Dept Anthropology, Univ Alberta.

Powers, WR and Hoffecker, J 1989 Late Pleistocene settlement in the Nenana Valley, central Alaska. Am Antiquity 54(2): 263-287.

Reeburgh, WS and Young, MS 1976 University of Alaska radiocarbon dates I. Radiocarbon 18(1): 1-15.

Stuckenrath, R and Mielke, JE 1973 Smithsonian Institution radiocarbon dates VIII. Radiocarbon 15(2): 388-424.

Sumodi, AJ 1974 Radioisotopes Laboratory radiocarbon date list I. Radiocarbon 16(2): 166-177.

West, FH 1975 Dating the Denali complex. Arctic Anthropology 12(1): 76-81. 1981 The archaeology of Beringia. New York, Columbia Univ Press, 268 pp. 